Kaganga: Jurnal Pendidikan Sejarah dan Riset Sosial Humaniora

Volume 2, Nomor 2, Desember 2019

e-ISSN : 2598-4934

p-ISSN : 2621-119X

DOI : https://doi.org/10.31539/kaganga.v2i2.940

\title{
PEMBELAJARAN SEJARAH MENJADI BERMAKNA DENGAN PENDEKATAN KONTEKTUAL
}

\author{
Yeni Asmara \\ STKIP PGRI Lubuklinggau \\ yeni.stkip@gmail.com
}

\begin{abstract}
ABSTRAK
Tujuan penelitian ini untuk mengetahui pembelajaran sejarah dengan pendekatan kontekstual. Penelitian ini berupa Studi Kepustakaan (Library Research) sebagai upaya dalam mengumpulkan informasi dan data dengan memanfaatkan dari sumbersumber tertulis yang ada di perpustakaan misalnya buku-buku, surat kabar, majalah, dokumen-dokumen yang relevan dengan permasalahan yang dibahas. Hasil penelitian, melalui pembelajaran sejarah guru dapat mengembangkan pemahaman siswa tentang masa lalu dengan melakukan pembelajaran yang dapat menghubungkan antara materi sejarah dengan situasi nyata di sekitar siswa, sehingga siswa dapat menggambarkan peristiwa masa lalu tesebut seperti yang ada dalam pelajaran sejarah. Adapun inovasi tersebut dikenal dengan istilah pembelajaran kontekstual yang memiliki prinsip-prinsip, asas-asas dalam penerapannya dengan mengaitkan antara materi yang dipelajari dengan kehidupan nyata siswa sehari-hari, baik dalam lingkungan keluarga, sekolah, masyarakat maupun warga negara, dengan tujuan untuk menemukan makna materi tersebut bagi kehidupannya. Dari hasil penelitian dapat disimpulkan pembelajaran konstektual dapat membantu siswa mempelajari sejarah masa lalu dengan siatuasi nyata disekitarnya.
\end{abstract}

Kata Kunci: Pembelajaran, Pendekatan Kontekstual

\section{ABSTRACT}

The purpose of this study was to determine the history of learning with a contextual approach. This research is in the form of a Library Study (Library Research) as an effort to collect information and data by utilizing written sources in the library such as books, newspapers, magazines, documents that are relevant to the issues discussed. The results of the study, through learning history teachers can develop students' understanding of the past by learning that can connect between historical material with real situations around students, so students can describe past events as they are in history lessons. The innovation is known as contextual learning that has principles, principles in its application by linking the material learned with the real life of daily students, both within the family, school, community and citizens, with the aim to find meaning the material for his life.From the results of this study, it can be concluded that contextual learning can help students learn past history with real situations around them.

Keywords: Learning, Contextual Approach 


\section{PENDAHULUAN}

$\begin{array}{rrr}\text { Pada } & \text { umumnya } & \text { proses } \\ \text { pembelajaran } & \text { sejarah } & \text { yang }\end{array}$ dilaksanakan di sekolah masih bersifat statis dan konvesional. Bersifat statis dapat diartikan tidak adanya perubahan yang dilakukan oleh guru sejarah dari waktu ke waktu hanya menggunakan metode konvensional seperti metode ceramah yang hanya membacakan atau pengulangan kalimat-kalimat yang ada di buku dan siswa hanya memiliki pengalaman belajar seperti mendengarkan, mencatat dan menghafal materi yang disajikan oleh guru tanpa mengerti apa yang dipelajari, tanpa mengerti apakah materi yang disampaikan atau yang dipelajari memiliki makna dan nilai yang berguna bagi kehidupan siswa sehingga memunculkan persepsi dari siswa bahwa pelajaran sejarah membosankan, menjenuhkan, kurang menarik, kurang penting untuk dipelajari.

Dalam penelitian yang dilakukan Alfian (2011) yang mengutif dari pakar pendidikan sejarah tentang fenomena pembelajaran sejarah di Indonesia menjelaskan bahwa dimulai dari tingkat SD sampai SLTA, pembelajaran sejarah yang dilaksanakan cenderung hanya memanfaatkan fakta sejarah sebagai materi utama, sehingga pendidikan disini terasa kering, tidak menarik, dan tidak memberi kesempatan kepada anak didik untuk belajar menggali makna dari sebuah peristiwa sejarah. Menurut Abdullah (Alfian, 2011) bahwa di sekolah pendidikan sejarah masih berorientasi pada pendekatan cronicle dan cenderung menuntut siswa untuk menghapal sesuatu peristiwa. Guru tidak membiasakan siswa untuk mengambil makna atau nilai-nilai dari materi sejarah yang diajarkan sehingga dapat dijadikan alat bagi siswa untuk memahami segala macam peristiwa yang terjadi untuk memahami adanya dinamika dari suatu perubahan.

Dari beberapa pendapat di atas umumnya pembelajaran sejarah yang terjadi di sekolah masih bersifat monoton, siswa belum mengerti tentang apa pentingnya mempelajari sejarah, siswa belum mampu memahami bahwasannya dalam setiap peristiwa sejarah terdapat nilai-nilai karakter yang sesungguhnya dapat dipelajari dan diteladani dalam kehidupan sehari-hari, pembelajaran sejarah dapat menjadikan manusia yang bijaksana ketika proses pembelajaran sejarah dilaksanakan baik dan benar.

Seperti yang dijelaskan oleh Hasan (2003) bahwa pembelajaran sejarah berperan dalam pembentukan karakter bangsa bagi generasi muda melalui pendidikan formal yang diharapkan dapat membentuk kesadaran sejarah yang secara moral dapat menumbuhkan nasionalisme peserta didik. Sebagai mata pelajaran yang berpotensi membentuk karakter bangsa, pembelajaran sejarah seharusnya tidak hanya mementingkan aspek pengetahuan atau kecerdasasan intelektual saja, melainkan mencakup aspek mentalitas atau kecerdasan emosional. Merupakan bagian dari upaya pembentukan karakter bangsa dimasa depan.

Permasalahan dewasa ini, mata pelajaran sejarah dianggap sebagian peserta didik tidak penting karena hanya bergelut dengan masa lalu. Bahkan yang lebih ironis lagi pelajaran 
sejarah identik dengan pelajaran menghafal sebuah kejadian yang sama dari dahulu sampai sekarang. Bahkan sebagian orang menggangap bahwa sejarah adalah mata pelajaran yang membosankan dan tidak menarik. Perlu disadari bahwa hal ini terjadi bukanlah karena materi sejarah yang tidak berbobot atau tidak penting lagi dipelajari, tetapi unsur - unsur dalam pembelajaran sejarah yang tidak mampu untuk menyesuaikan dengan kondisi hari ini. Artinya, perlu ada inovasi dari unsur terkait dalam pembelajaran sejarah. Salah satu unsur yang sangat berpengaruh adalah unsur manusiawi yang terdiri dari guru dan siswa.

Guru memiliki peran penting dalam pembelajaran sejarah karena sebagai tenaga pendidik diharapkan akan menggerakan unsur unsur yang ada pada pembelajaran sejarah. Sebagai tenaga pendidik dalam mata pelajaran sejarah, guru harus mampu menghadirkan sesuatu yang baru baik terkait dengan model, stretegi, metode, sampai pada penggunaan media pembelajaran yang tepat dengan kondisi hari ini. Guru harus mampu membawa siswa ke pengalaman masa lalu kehidupan manusia Indonesia karena memang karakteristik dari pembelajaran sejarah yang diakronis (melebar pada waktu) memerlukan suatu strategi untuk dapat mengubah paradigm pembelajaran sejarah yang membosankan menjadi pembelajaran yang bermakna dan menyenangkan bagi siswa.

Untuk mencapai hal tersebut bukanlah suatu pekerjaan yang mudah, diperlukan kemampuan untuk mencipta hal-hal baru dari guru agar dapat membawa pelajaran sejarah menjadi sesuatu yang penting bagi peserta didik, dan juga tentu dapat menghilangkan label pelajaran sejarah yang menghafal dan membosankan diperlukan kreativitas guru serta didukung juga oleh kecerdasan, latar belakang pendidikan, motivasi ataupun etos kerja dari guru tersebut.

Melalui pendidikan sejarah peserta didik diajak menelaah keterkaitan kehidupan yang di alami diri, masyarakat dan bangsanya , sehingga mereka tumbuh menjadi generasi muda yang memiliki kesadaran sejarah, mendapatkan inspirasi ataupun hikmah dari kisah kisah pahlawan, maupun tragedi nasional , yang pada akhirnya memdorong terbentuknya pola berfikir ke arah berfikir secara rasional - kritis -empiris , dan yang tidak kalah pentingnya ialah pembelajaran sejarah yang mengembangkan sikap mau menghargai nilai - nilai kemanusiaan .

Untuk mencapai tujuan pembelajaran tersebut diperlukan upaya inovasi dan kreatifitas dari guru sejarah salah satunya dengan menggunakan pendekatan pembelajaran kontektual dalam menyajikan materi sejarah sehingga paradigma pembelajaran sejarah yang membosankan dapat diganti dengan pembelajaran sejarah yang bermakna. Ketika pembelajaran sejarah dirasakan memiliki makna bagi yang mempelajarinya, maka pada saat itulah proses internalisasi nilai-nilai karakter akan mengakar dalam diri siswa dan apa yang menjadi tujuan pembelajaran sejarah dapat tercapai.

Menurut Muchit (2007) menjelaskan bahwa pembelajaran kontektual bukanlah suatu model dalam pembejaran tetapi lebih 
dimaksudkan sebagai suatu kemampuan guru dalam melaksanakan proses pembelajaran yang lebih mengedepankan idealitas pendidikan sehingga benar-benar dapat menghasilkan kualitas pembelajaran yang efektif dan efisien. Dijelaskan juga oleh Wiyanarti bahwa pembelajaran kontekstual atau CTL dapat dimaknai sebagai sebuah strategi pembelajaran yang membantu guru mengaitkan antara materi yang diajarkan dengan melibatkan pengalaman dari peserta didik. Menurut Priansa (2015) menjelaskan bahwa pembelajaran kontektual dapat membuat peserta didik terlibat dalam kegiatan yang bermakna, belajar tidak hanya sekedar menghafal tetapi peserta didik dapat mengonstruksikan pengetahuan yang dimiliki dengan cara mengaplikasikan pengetahuan yang dimiliki pada realita kehidupan seharihari.

Dari pendapat di atas apabila dihubungkan dengan pembelajaran sejarah artinya guru dituntut untuk mengembangkan kesadaran sejarah dengan menggunakan pembelajaran kontektual tersebut untuk menjadikan pembelajaran sejarah yang bermakna serta mengharapkan peserta didik untuk memperoleh materi pelajaran meskipun sedikit tetapi mendalam bukan banyak tetapi kurang bermakna.

\section{METODE PENELITIAN}

Penelitian ini berupa Studi Kepustakaan (Library Research) sebagai upaya dalam mengumpulkan informasi dan data dengan memanfaatkan dari sumber-sumber tertulis yang ada di perpustakaan misalnya buku-buku, surat kabar, majalah, dokumen-dokumen yang relevan dengan permasalahan yang dibahas. Dapat diartikan Studi kepustakaan merupakan teknik pengumpulan data dengan melakukan penelaahan terhadap buku, literatur, catatan, serta berbagai laporan yang berkaitan dengan masalah yang ingin dipecahkan atau kajian teoritis, referensi serta literatur ilmiah lainnya yang berkaitan dengan budaya, nilai dan norma yang berkembang pada situasi sosial yang diteliti (Sugiyono, 2012).

\section{HASIL DAN PEMBAHASAN \\ Pembelajaran Sejarah}

Pembelajaran sejarah memiliki peran fundamental dalam kaitannya dengan guna atau tujuan dari belajar sejarah. Pembelajaran sejarah diharapkan dapat menumbuhkan wawasan peserta didik untuk belajar dan sadar guna dari sejarah bagi kehidupan sehari-hari sebagai individu maupun bangsa. Selayaknya pembelajaran sejarah mengacu pada guna belajar sejarah, maka perlu dikembangkan ragam pendekatan pembelajaran sejarah. Guna belajar sejarah dari perspektif tujuan pembelajaran sejarah menyangkut aspek kognitif, afektif dan psikomotor yang merupakan kesatuan bersifat unity, sehingga output pembelajaran sejarah adalah siswa yang memiliki pengetahuan, penghayatan dan prilaku sesuai nilai-nilai sejarah yang dipelajari (Isjoni, 2007).

Pembelajaran sejarah agar menarik dan menyenangkan dapat dilaksanakan dengan berbagai cara antara lain dengan mengajak siswa pada peristiwa-peristiwa sejarah yang terjadi di sekitar mereka. Lingkungan di sekitar siswa terdapat berbagai 
peristiwa sejarah yang dapat membantu guru untuk mengembangkan pemahaman siswa tentang masa lalu. Umumnya siswa akan lebih tertarik dengan pelajaran sejarah apabila berhubungan dengan situasi nyata di sekitarnya, sehingga siswa dapat menggambarkan peristiwa masa lalu tesebut seperti yang ada dalam pelajaran sejarah.

Sebagai suatu mata pelajaran di sekolah, sejarah merupakan matapelajaran yang tertua dibandingkan dengan disiplin ilmu sosial lainnya, bahkan pendidikan sejarah diajarkan di sekolah sejak zaman penjajahan, sesudah kemerdekaan sampai dengan sekarang (Hasan, 2003). Peranan pendidikan sejarah sebagai landasan utama bagi pendidikan IPS dalam menginternalisasikan nilai-nilai seperti pengenalan identitas diri, empati, toleransi dalam menumbuhkan sense of belonging dan sense of solidarity sebagai upaya pembentukan identitas nasional.

Disamping itu pembelajaran sejarah memiliki tujuan dan manfaat seperti memperoleh pengalaman yang bermakna dari peristiwa-peristiwa di masa lalu,sehingga dapat mengambil hikma dari kesalahan-kesalahan tersebut tidak terulang kembali,dan mampu bertindak lebih arif dan bijaksana terutama dalam pengambilan keputusan. Oleh karena itu sudah selayaknya generasi muda menyenangi untuk belajar sejarah, sebab menurut Cleaf (Isjoni, 2007) menjelaskan"History should help children develop an understanding and appreciation of their heritage and tradition. Children should then be able to compare the progress of their nation with other nations" (Pembelajaran sejarah dan pemahaman tentang sejarah akan dapat membantu anakanak mengembangkan pengertian dan penghargaan tentang warisan dan tradisi mereka. Anak-anak kemudian akan mampu membandingkan kemajuan negaranya dengan negara lain).

Pembelajaran sejarah di sekolah bertujuan membangun kepribadian dan sikap mental anak didik, membangkitkan keinsyafan akan suatu dimensi fundamental dalam eksistensi umat manusia (kontinuitas gerakan dan peralihan terus menerus dari yang lalu kea rah masa depan), mengantarkan peserta didik pada sifat kejujuran dan kebijaksanaan pada anak didik, serta menanamkan cinta bangsa dan sikap kemanusian. Artipenting pelajaran sejarah adalah dapat memecahkan masalah masa kini dengan menggunakan masa lampau.

Untuk itu dalam pembelajaran sejarah hendaknya dilakukan tiga tahap (Abdullah, 1996) pertama memupuk kesadaran atas lingkungan sosial, rasa keakraban (sense of intimacy), kedua memperkenalkan siswa pada makna dari dimensi waktu kehidupan (sense of actuality), ketiga rasa hayat sejarah (sense of history) pelajaran sejarah tidak didominasi sejarah politik, tetapi sosial sehingga dapat menumbuhkan kreatifitas lokal yang berguna bagi lingkungan alam maupun menghadapi tantangan di masa depan.

Dari penjelasan di atas
mendeskripsikan
bermanfaatnya pelajaran sejarah bagi
peserta didik tidak hanya dalam aspek
kognitif, tetapi juga aspek afektif dan
psikomotor dengan melakukan sebuh


upya inovasi dan kreatifitas dari guru sejarah dalam menyajikan materi sejarah, sehingga kebermaknaan dari pembelajaran sejarah itu sendiri dapat diperoleh oleh siswa dan lebih dari itu siswa mampu menginternalisasikan dan mengimplementasikannya dalam kehidupan sehari-hari. Oleh karena itu di era saat ini sudah sepantasnya guru sejarah merubah paradigma pembelajaran sejarah yang membosankan, kurang penting dipelajari dapat diubah menjadi pembelajaran sejarah yang menyenangkan dan bermakna. Diantaranya guru sejarah dapat menerapkan suatu pendekatan pembelajaran kontekstual untuk mencapai tujuan tersebut dalam bentuk menghubungkan materi dalam buku teks dengan lingkungan sekitar siswa dan penuh makna, yang dapat memberikan konribusi dalam penyelesaian masalah.

\section{Pendekatan Pembelajaran Kontekstual}

Dalam bahasa Inggris kontekstual berasal dari kata "context" yang dapat dipahami sebagai bagian suatu uraian atau kalimat yang dapat mendukung atau menambah kejelasan makna, situasi yang ada hubungannya dengan suatu kejadian. Dapat diartikan kontektual adalah sesuatu yang berhubungan dengan konteks. Menurut Suprijono (2010), pendekatan pembelajaran kontekstual atau disebut juga dengan Contexstual Teaching and Learning (CTL) adalah suatu konsep yang membantu guru mengaitkan antara materi yang diajarkannya dengan situasi dunia nyata, dan mendorong peserta didik membuat hubungan antara pengetahuan yang dimilikinya dengan penerapannya dalam kehidupan mereka sebagai anggota keluarga dan masyarakat. Pendekatan pembelajaran kontekstual merupakan prosedur pendidikan yang bertujuan membantu peserta didik memahami makna bahan pelajaran yang mereka pelajari, dengan cara menghubungkannya dengan konteks kehidupan mereka sendiri dalam lingkungan sosial dan budaya masyarakat. Sehingga, proses belajar tidak hanya berpengaruh pada hasil belajar yang menjadi tujuan pembelajaran, namun memberikan kebermaknaan pengetahuan dan pengalaman yang bermanfaat dalam konteks dunia nyata peserta didik.

Jhonson (2007) mengungkapkan bahwa pembelajaran kontekstual adalah suatu pendekatan pendidikan yang berbeda, melakukan lebih dari pada menuntun para peserta didik dalam menggabungkan subjek-subjek akademik dengan konteks dalam keadaan mereka sendiri. Pembelajaran kontekstual merupakan sebuah pembelajaran yang dapat memberikan dukungan dan penguatan pemahaman konsep peserta didikk dalam menyerap sejumlah materi pembelajaran serta mampu memperoleh makna dari apa yang mereka pelajari dan mampu menghubungkannya dengan kehidupan nyata sehari-hari. Dengan kata lain pembelajaran kontektual bertujuan membantu peserta didik dalam memaknai suatu materi yang dipelajari dengan mengaitkan pada konteks kehidupan keseharian mereka, baik keadaan pribadi, sosial, dan budaya.

Hal ini berarti, bahwa pembelajaran kontekstual memungkinkan siswa menghubungkan isi materi dengan konteks kehidupan 
sehari-hari untuk menemukan makna. Sanjaya (2006) mengemukakan bahwa pendekatan pembelajaran kontekstual adalah suatu pendekatan pembelajaran yang menekankan kepada proses keterlibatan siswa secara penuh, untuk dapat memahami materi yang dipelajari, dan menghubungkannya dengan situasi kehidupan nyata, sehingga mendorong siswa untuk dapat menerapkannya dalam kehidupan mereka.

Penjelasan lebih lanjut dikemukakan oleh Muchith (2008), bahwa pendekatan kontekstual merupakan pembelajaran yang bermakna dan menganggap tujuan pembelajaran adalah situasi yang ada dalam konteks tersebut, konteks itu membantu siswa dalam belajar bermakna dan juga untuk menyatakan hal-hal yang abstrak. Hal yang sama dikemukakan oleh oleh Komalasari (2010), tentang pendekatan pembelajaran kontekstual merupakan pendekatan pembelajaran yang mengaitkan antara materi yang dipelajari dengan kehidupan nyata siswa sehari-hari, baik dalam lingkungan keluarga, sekolah, masyarakat maupun warga negara, dengan tujuan untuk menemukan makna materi tersebut bagi kehidupannya.

Dari beberapa pendapat di atas bahwa pendekatan pembelajaran kontekstual sangat baik jika diterapkan dalam proses pembelajaran agar tercapainya tujuan pembelajaran dan menjadikan pembelajaran yang bermakna bagi siswa, dikarenakan guru dengan menggunakan pendekatan kontekstual berupaya mengaitkan antara materi yang terdapat di buku teks dengan pengalaman nyata dari kehidupan siswa baik dilingkungan keluarga, sekolah, masyarakat bangsa dan negara.

Perlunya menerapkan pendekatan pembelajaran kontekstual oleh guru dalam penyajian suatu materi dikarenakan; 1. Proses pembelajaran di sekolah pada umumnya masih bersifat teacher centred penyampaian materi oleh guru, dan siswa "diharuskan" menyimak, memperhatikan dan menerimanya, sehingga proses pembelajaran kurang menyenangkan dan memberdayakan siswa. 2. Pada umumnya materi pembelajaran bersifat abstrak-teoritisakademis, kurang menyentuh dengan masalah-masalah yang dihadapi siswa dalam kehidupan sehari-hari di lingkungan keluarga, masyarakat, alam sekitar dan dunia kerja. 3.

Penilaian hanya dilakukan dengan tes yang menekankan pengetahuan, tidak menilai kualitas dan kemampuan belajar siswa yang autentik pada situasi yang autentik. 4 . Sumber belajar masih terfokus pada guru dan buku. Lingkungan sekitar belum dimanfaatkan secara optimal. Pembelajaran dikatakan mengunakan pendekatan kontekstual jika materi pembelajaran tidak hanya tekstual melainkan dikaitkan dengan peneapannya dalam kehidupan seharihari siswa di lingkungan keluarga, masyarakat, alam sekitar, dan dunia kerja, dengan melibatkan ketujuh komponen utama tersebut sehinggga pembelajaran menjadi bermaknabagi siswa.

Dalam

penerapannya pembelajaran kontekstual tidak memerlukan biaya besar dan media khusus. Pembelajaran kontekstual memanfaatkan berbagai sumber dan 
media pembelajaran yang ada di lingkungan sekitar. Oleh sebab itu dalam pembelajaran kontekstual rencana pelaksanaan pembelajaran (RPP) sebenarnya lebih bersifat sebagai rencana pribadi dari pada sebagai laporan untuk kepala sekolah atau pengawas seperti yang dilakukan saat ini. jadi RPP lebih cenderung berfungs mengingatkan guru sendiri dalam menyapkan alat-alat atau media dan mengendalikan langkah-langkah (skenario) pembelajaran sehingga bentuknya lebih sederhana.

Beberapa model pembelajaran yang meruapakan aplikasi pembelajaran kontekstual antara lain model pembelajaran langsung (direct instruction), pembelajaran koperatif (cooperatif learning), pembelajaran berbasis masalah ( problem based learning). Berdasarkan beberapa pendapat yang telah dikemukakan para ahli, peneliti menyimpulkan bahwa pendekatan kontekstual merupakan pendekatan dengan konsep belajar mengajar yang mengaitkan antara materi yang diajarkan oleh guru dengan situasi dunia nyata siswa, dan mendorong siswa untuk membuat hubungan antara pengetahuan yang dimilikinya dengan penerapannya dalam kehidupan nyata.

\section{Karakteristik Pendekatan Pembelajaran Kontekstual}

Pembelajaran kontekstual memiliki beberapa karakteristik yang khas, yang membedakannya dengan pendekatan pembelajaran lain. Karakteristik pendekatan kontekstual menurut Depdiknas (2003) adalah: (a) kerjasama, (b) saling menunjang, (c) menyenangkan, (d) tidak membosankan, (e) belajar dengan gairah, (f) pembelajaran terintegrasi, (g) siswa aktif, (h) sharing dengan teman, (i) menggunakan berbagai sumber, (j) siswa kritis dan guru kreatif, (k) dinding kelas dan loronglorong penuh dengan hasil karya siswa, dan (1) laporan kepada orang tua bukan rapor, melainkan hasil karya siswa. Pendekatan pengajaran kontekstual harus menekankan pada hal-hal sebagai berikut. a. Belajar berbasis masalah (problem-based learning) b. Pengajaran autentik (authentic instruction) c. Belajar berbasis inkuiri (inquiry-based learning) d. Belajar berbasis proyek (project-based learning) e. Belajar berbasis kerja (work-based learning) $\mathrm{f}$. Belajar jasa layanan (service learning) g. Belajar kooperatif (cooperative learning).

Sementara itu, Jhonson (Priansa, 2015) terdapat delapan komponen utama dalam pembelajaran kontekstual seperti yang ditampilkan pada table 1 berikut ini:

Tabel1Karakteristik Pembelajaran Kontekstual

\begin{tabular}{|c|c|c|}
\hline No & Kakteristik & Penjelasan \\
\hline 1. & $\begin{array}{l}\text { Melakukan } \\
\text { hubungan } \\
\text { Bermakna } \\
\text { (Making } \\
\text { Meaningful } \\
\text { Connection) }\end{array}$ & $\begin{array}{l}\text { Peserta didik dapat } \\
\text { mengatur diri } \\
\text { sendiri sebagai } \\
\text { orang yang belajar } \\
\text { secara aktif dalam } \\
\text { mengembangkan } \\
\text { minatnya secara } \\
\text { individual, dapat } \\
\text { bekerja sendiri atau } \\
\text { kelompok, dan } \\
\text { dapat belajar sambil } \\
\text { berbuat (learning } \\
\text { by doing). }\end{array}$ \\
\hline 2. & $\begin{array}{l}\text { Melakukan } \\
\text { kegiatan yang } \\
\text { signifikan (Doing } \\
\text { Significant Work) }\end{array}$ & $\begin{array}{l}\text { Peserta } \\
\text { melakukan } \\
\text { pekerjaan } \\
\text { signifikan, } \\
\text { tujuan, }\end{array}$ \\
\hline
\end{tabular}




\begin{tabular}{|c|c|c|}
\hline & & urusannya dengan \\
\hline & & $\begin{array}{l}\text { orang lain, ada } \\
\text { hubungannya } \\
\text { dengan penentuan } \\
\text { pilihan, dan ada } \\
\text { produk atau hasil } \\
\text { yang sifatnya nyata. }\end{array}$ \\
\hline 3 & $\begin{array}{lr}\text { Belajar } & \text { yang } \\
\text { diatur } & \text { sendiri } \\
\text { (Self Regulated } \\
\text { Learning) }\end{array}$ & 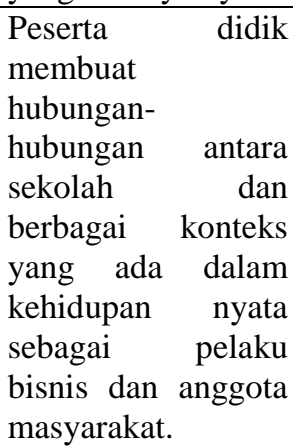 \\
\hline 4. & $\begin{array}{l}\text { Bekerja sama } \\
\text { (Colaborating) }\end{array}$ & $\begin{array}{l}\text { Peserta didik dapat } \\
\text { bekerjasama } \\
\text { dengan melibatkan } \\
\text { guru } \\
\text { pembuatan } \\
\text { kelompok belajar } \\
\text { sehingga dapat } \\
\text { membantu siswa } \\
\text { untuk saling } \\
\text { memahami, } \\
\text { mempengaruhi dan } \\
\text { berkomunikasi. }\end{array}$ \\
\hline 5. & $\begin{array}{l}\text { Berpikir Kritis } \\
\text { dan Kreatif } \\
\text { Critical and } \\
\text { creative } \\
\text { Thingking) }\end{array}$ & $\begin{array}{l}\text { Peserta didik dapat } \\
\text { menganalisis, } \\
\text { membuat sintesis, } \\
\text { memecahkan } \\
\text { masalah, membuat } \\
\text { keputusan, dan } \\
\text { menggunakan } \\
\text { logika serta bukti- } \\
\text { bukti dalam } \\
\text { memecahkan } \\
\text { masalah. }\end{array}$ \\
\hline 6. & $\begin{array}{l}\text { Memelihara } \\
\text { Peserta didik } \\
\text { (Nurturing the } \\
\text { Individual) }\end{array}$ & $\begin{array}{l}\text { Peserta didik } \\
\text { memelihara } \\
\text { pribadinya dengan } \\
\text { mengetahui, } \\
\text { member perhatian, } \\
\text { memiliki harapan } \\
\text { tinggi, memotivasi } \\
\text { dan memperkuat } \\
\text { diri sendiri serta } \\
\text { kemampuan peserta } \\
\text { didik dalam } \\
\text { menghormati orang }\end{array}$ \\
\hline
\end{tabular}

\begin{tabular}{|c|c|c|}
\hline & & dewasa. \\
\hline 7. & $\begin{array}{l}\text { Mencapai } \\
\text { Standar yang } \\
\text { tinggia (Reaching } \\
\text { High Standard) }\end{array}$ & $\begin{array}{l}\text { Peserta didik } \\
\text { mampu } \\
\text { mengidentifikasi } \\
\text { tujuan dan } \\
\text { termotivasi } \\
\text { mencapai } \\
\text { tujuannya. }\end{array}$ \\
\hline 8. & \begin{tabular}{l}
\multicolumn{2}{l}{ Menggunakan } \\
penilaian yang \\
Autentik (using \\
Authentic \\
Assesment)
\end{tabular} & $\begin{array}{lr}\text { Penilaian } & \text { autentik } \\
\text { diarahkan } & \text { pada } \\
\text { proses mengamati, } & \text { dan } \\
\text { menganalisis } & \text { data } \\
\text { menafsirkan } & \text { data } \\
\text { yang } & \text { telah } \\
\text { terkumpul dari } \\
\text { peserta } \\
\text { selama didik } \\
\text { pembelajaran } \\
\text { berlangsung } \\
\text { berbentuk } \\
\text { portofolio, yang } \\
\text { kelompok, tugas } \\
\text { demontrasi } \\
\text { laporan tertulis. }\end{array}$ \\
\hline
\end{tabular}

Ada lima karakteristik penting dalam pembelajaran kontektual yakni: pertama, pengaktifan pengetahuan yang sudah ada (Activate Knowledge) artinya pengetahuan yang akan diperoleh peserta didik merupakan pengetahuan yang memiliki keterkaitan antara yang satu dengan yang lainnya. Kedua, Pengetahuan Baru ( Acquiring Knowledge) artinya pembelajaran dimulai dengan mempelajari seluruhnya kemudian memperhatikan detailnya. Ketiga, pemahaman pengetahuan (Understanding Knowledge) pengetahuan yang diperoleh bukan untuk dihafal melainkan untuk dipahami dan diyakini dengan cara meminta tanggapan dari yang lain. Keempat, mempraktikkan pengetahuan ( Applying Knowledge) Perubahan tingkah laku peserta didik yang diperolehnya dari pengetahuan, harus 
dapat diaplikasikan dalam kehidupan sehari-hari.

Kelima, melakukan refleksi (Reflecting Knowledge) sebagai bentuk adanya upaya dalam proses perbaikan atau penyempurnaan strategi pengembangan pengetahuan. Trianto (2014) menambahkan bahwa karaketristik pendekatan kontekstual, yaitu (1) kerjasama; (2) saling menunjang; (3) menyenangkan, mengasyikkan; (4) tidak membosankan (joyfull, comfortable); (5) belajar dengan bergairah; (6) pembelajaran terintegrasi; dan (7) menggunakan berbagai sumber siswa aktif. Penjelasan lebih lanjut dikemukakan oleh Komalasari (2010) bahwa karakteristik pembelajaran kontekstual meliputi pembelajaran yang menerapkan konsep keterkaitan (relating), konsep pengalaman langsung (experiencing), konsep aplikasi (applying), konsep kerjasama (cooperating), konsep pengaturan diri (self-regulating), dan konsep penilaian autentik (authentic assessment). Berdasarkan berbagai pendapat para ahli tersebut, peneliti menyimpulkan bahwa pendekatan kontekstual memiliki ciri khusus, yakni pembelajaran yang mengaitkan materi pembelajaran dengan situasi kehidupan nyata, mengarahkan siswa untuk berpikir kritis dengan melakukan eksplorasi terhadap konsep dan informasi yang dipelajari.

Berdasarkan uraian pendapat tersebut, dapat disimpulkan bahwa penerapan pendekatan kontekstual dalam proses pembelajaran memiliki komponen yang komprehensif. Komponen-komponen tersebut mencakup proses konstruktivis, melakukan proses berpikir secara sistematis melalui inkuiri, kegiatan bertanya antara siswa dengan guru maupun sesame siswa, membentuk kerjasama antarsiswa melalui diskusi, adanya peran model untuk membantu proses pembelajaran, melibatkan siswa dalam melakukan refleksi pembelajaran, serta penilaian sebenarnya yang dilakukan selama proses pembelajaran berlangsung sampai diperoleh hasil belajar.

\section{Tujuan Pembelajaran Kontekstual}

Pembelajaran kontektual bertujuan untuk meningkatkan prestasi belajar peserta didik melalui peningkatan pemahaman konsep makna materi pelajaran yang dipelajarinya dengan mengkaitkan antara materi yang dipelajari dengan konteks kehidupan mereka, keluarga, warga negara dan sebagai calon pegawai dimasa yang akan datang. Tujuan tersebut akan tercapai jika didukung oleh guru yang memiliki wawasan kontekstual yang tepat; memahami materi pembelajaran yang bermakna bagi peserta didik; memiliki strategi, metode dan teknik belajar mengajar yang mampu mengaktifkan semangat belajar peserta didik, memiliki alat peraga pendidikan yang bernuansa kontekstual, suasana dan iklim sekolah yang juga bernuansa kontekstual sehingga situasi kehidupan sekolah dapat seperti kehidupan nyata di lingkungan peserta didik.

Pembelajaran

kontektual mendorong pembelajaran yang menyenangkan dan tidak membosankan sehingga peserta didik mampu melaksanakan kerjasama, belajar secara aktif, berbagi sumber pengetahuan diantara peserta didik, 
mendorong pemikiran kritis dan kreatif.

\section{Teori-teori yang melandasi pembelajaran kontekstual}

Ada beberapa teori yang melandasi pembelajaran kontekstual menurut Suryanti (Priansa, 2015) yang disajikan dalam Tabel.2 berikut ini :

Tabel 2 Teori Pembelajaran Kontekstual

\begin{tabular}{|c|c|c|}
\hline No & Teori & Penjelasan \\
\hline 1. & $\begin{array}{l}\text { Berbasis } \\
\text { Pengetahuan } \\
\text { (knowledge-Based } \\
\text { Constructivism) }\end{array}$ & $\begin{array}{l}\text { Teori yang } \\
\text { menekankan } \\
\text { pada pentingnya } \\
\text { mengembangkan } \\
\text { kemampuan }\end{array}$ \\
\hline 2. & $\begin{array}{l}\text { Pembelajaran } \\
\text { Berbasis Usaha/Teori } \\
\text { Pertumbuhan } \\
\text { Kecerdasan (Effort- } \\
\text { Based } \\
\text { Learning/incremental } \\
\text { theory of } \\
\text { intelligence) }\end{array}$ & $\begin{array}{l}\text { Teori yang } \\
\text { menekankan } \\
\text { pada upaya } \\
\text { keras untuk } \\
\text { mencapai tujuan } \\
\text { belajar, hal ini } \\
\text { akan memotivasi } \\
\text { seseorang untuk } \\
\text { terlibat dalam } \\
\text { kegiatan yang } \\
\text { berkaitan } \\
\text { dengan } \\
\text { komitmen untuk } \\
\text { belajar. }\end{array}$ \\
\hline 3. & $\begin{array}{l}\text { Sosialisasi } \\
\text { (Socialization) }\end{array}$ & $\begin{array}{l}\text { Teori yang } \\
\text { menekankan } \\
\text { bahwa bahwa } \\
\text { belajar } \\
\text { merupakan } \\
\text { proses sosial } \\
\text { yang } \\
\text { menentukan } \\
\text { tujuan belajar, } \\
\text { oleh karenanya } \\
\text { factor sosial dan } \\
\text { budaya perlu } \\
\text { diperhatikan } \\
\text { selama } \\
\text { perencanaan } \\
\text { pengajaran }\end{array}$ \\
\hline 4. & $\begin{array}{l}\text { Pembelajaran Situasi } \\
\text { (Situated Learning) }\end{array}$ & $\begin{array}{l}\text { Teori yang } \\
\text { menekankan } \\
\text { bahwa }\end{array}$ \\
\hline
\end{tabular}

pengetahuan dan pembelajaran harus dikondisikan dalam fisik tertentu dan dalam konteks sosial (masyarakat, rumah, dsb) dalam mencapai tujuan belajar.

\begin{tabular}{|c|c|c|}
\hline 5. & $\begin{array}{l}\text { Pembelajaran } \\
\text { Distribusi } \\
\text { (Distributed } \\
\text { Learning) }\end{array}$ & $\begin{array}{l}\text { Teori yang } \\
\text { menekankan } \\
\text { bahwa manusia } \\
\text { merupakan } \\
\text { bagian } \\
\text { terintegrasi dari } \\
\text { proses } \\
\text { pembelajaran } \\
\text { oleh karenanya } \\
\text { harus berbagi } \\
\text { pengetahuan dan } \\
\text { tugas-tugas pada } \\
\text { individu lain } \\
\text { serta lingkungan } \\
\text { sekitar. }\end{array}$ \\
\hline
\end{tabular}

\section{Asas-Asas yang Melandasi Pembelajaran Kontekstual}

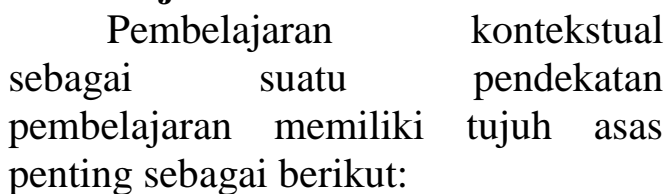

1. Konstruktivisme, merupakan proses membangun atau menyusun pengetahuan baru dalam struktur kognitif peserta didik berdasarkan pengalaman. Menurut konstruktivisme, pengetahuan itu memang berasal dari luar akan tetapi dikonstruksi oleh dan dari dalam diri seseorang. Sehingga pengetahuan bersifat dinamis tergantung yang melihat dan mengonstruksinya.

2. Inkuiri, proses pembelajaran didasarkan pada pencarian dan penemuan melalui proses berpikir 
secara sistematis. Dengan demikian dalam proses perencanaan, guru bukanlah mempersiapkan materi yang harus dihafal, akan tetapi merancang pembelajaran yang memungkinkan peserta didik dapat menemukan sendiri materi yang harus dipahaminya. Sehingga diharapkan peserta didik dapat mengembangkan intelektual, emosional dan pribadinya.

3. Bertanya (Questioning), dalam proses pembelajaran kontekstual guru diharapkan dapat menggali informasi dari siswa dengan cara bertanya dengan tujuan untuk mengetahui kemampuan peserta didik dalam penguasaan materi pelajaran, membangkitkan motivasi peserta didik untuk belajar, merangsang keingintahuan peserta didik terhadap sesuatu dan memfokuskan peserta didik pada sesuatu yang diinginkan, membimbing peserta didik untuk menemukan atau menyimpulkan sesuatu.

4. Masyarakat Belajar (Learning Community) sangat penting dalam pembelajaran kontektual dengan menerapkan pembelajaran melalui kelompok belajar dengan tujuan yang memiliki kemampuan tertentu didorong untuk menularkan pada yang lain.

5. Pemodelan (Modeling), proses pembelajaran dengan menggunakan sesuatu contoh yang dapat ditiru oleh setiap peserta didik. Sehingga terhindar dari pembelajaran yang teoritis-abstrak yang memungkinkan terjadinya verbalisme.

6. Refleksi (Reflection), proses pengendapan pengalaman yang telah dipelajari, dilakukan dengan cara mengurutkan kembali kejadian atau peristiwa pembelajaran yang telah dilaluinya.

7. Penilaian nyata (Authentic Assesment), proses yang dilakukan guru untuk mengumpulkan informasi tentang perkembangan belajar yang dilakukan peserta didik.

Prinsip-Prinsip Pendekatan Pembelajaran Kontektual juga dijelaskan Johnson (2007) minimal memiliki tiga prinsip utama yakni; Saling Ketergantungan artinya peserta didik dalam lingkungan sekolah memiliki hubungan ketergantungan dengan guru, kepala sekolah, tata usaha, media dan sumber belajar, sarana prasarana belajar, iklim dan lingkungan sekolah. Prinsip Diferensiasi yaitu para pendidik dituntuk untuk mendidik, mengajar, melatih dan membimbing peserta didik dengan memperhatikan perubahanperubahan yang ada. Prinsip organisasi yaitu menuntut para pendidik dan para pengajar di sekolah agar mendorong setiap peserta didiknya untuk memahami dan menerapkan semua potensi yang dimiliki seoptimal mungkin.

\section{Langkah-langkah \\ Pendekatan Kontekstual}

\section{Penerapan Pembelajaran} Setiap pendekatan, model, atau teknik pembelajaran memiliki prosedur pelaksanaan yang terstruktur sesuai dengan karakteristiknya. Begitupun dengan pendekatan kontekstual, berikut ini langkahlangkah penerapan pendekatan kontekstual dalam pembelajaran yang dikemukakan oleh Trianto (2014), 
yaitu: a. Kembangkan pemikiran bahwa siswa akan belajar lebih bermakna dengan cara bekerja sendiri, dan mengkonstruksi sendiri pengetahuan dan keterampilan bertanya. b. Laksanakan sejauh mungkin kegiatan inkuiri untuk semua topik. c. Kembangkan sifat ingin tahu siswa dengan bertanya. d. Ciptakan masyarakat belajar. e. Hadirkan model sebagai contoh pembelajaran. f. Lakukan refleksi di akhir pertemuan. g. Lakukan penilaian yang sebenarnya (authentic assesment) dengan berbagai cara.

Pendapat selaras dikemukakan oleh Mulyasa (2013), bahwa terdapat lima elemen yang harus diperhatikan dalam pelaksanaan pendekatan kontekstual, yakni: a. Pembelajaran harus memperhatikan pengetahuan yang sudah dimiliki oleh peserta didik. b. Pembelajaran dimulai dari keseluruhan (global) menuju bagianbagiannya secara khusus (dari umum ke khusus). c. Pembelajaran harus ditekankan pada pemahaman, dengan cara: 1) menyusun konsep sementara 2) melakukan sharing untuk memperoleh masukan dan tanggapan dari orang lain 3) merevisi dan mengembangkan konsep. $d$. Pembelajaran ditekankan pada upaya mempraktikkan secara langsung apaapa yang dipelajari. e. Adanya refleksi terhadap strategi pembelajaran dan pengembangan pengetahuan yang dipelajari.

Sementara itu Ghofur (2003:42) menjelaskan langkah-langkah pembelajaran konekstual yakni :

Pembelajaran pendahuluan (PreInstructional Activities) dikembangkan dengan kegiatan lain yang merupakan penjabaran dari prinsip "keterkaitan" (relating) yang meliputi; pemberian tujuan, ruang lingkup matrei(akan lebih baik dilengkapi peta konsep yang menggambarkan struktur atau jalinan antara materi), manfaat atau kegunaan suatu topic baik untuk keperluan sekarang maupun belajar yang akan datang, manfaat atau relefansinya untuk bekerja dikemudian hari serta berbagai hal terkait lainnya. Sehingga dari kegiatan pendahuluan dapat diketahui kesiapan peserta didik untuk menerima materi pembelajaran.

Menyampaiakan materi pelajaran (presenting instructional materials) dengan menggunakan metode penyajian seperti inquisitor, discovery, diskusi, inventori, induktif atau penelitian mandiri serta penggunaan alat peraga.

Pemancingan penampilan peserta didik (Eliciting Performance) peserta didik lebih banyak berperan aktif dalam pembelajaran dari pada guru dengan berorientasi pada kegiatan pelatihan dan penerapan konsep serta prinsip yang dipelajari dalm konteks dan situasi yang berbeda bukan hanya sekedar kegiatan menghafal.

Pemberian umpan balik (Providing Feedback) informasih yang diberikan kepada peserta didik mengenai kemajuan belajarnya yang dapat dilaksanakan selama proses pembelajaran berlangsung baik dalam penilaian pretes, penilaian proses dan post test. e. Kegiatan tindak lanjut (Follow Up Activities) yakni kegiatan tindak lanjut berupa mentranfer pengetahuan (transferring) dan pemberian pengayaan (enrichment).

Berdasarkan paparan pendapat tersebut, peneliti menyimpulkan bahwa langkah-langkah dalam penerapan pendekatan kontekstual, 
diawali dengan pengonstruksian pengetahuan yang dimiliki siswa dengan materi yang akan dipelajari, dan dikaitkan dengan konteks dunia nyata. Mengembangkan pengetahuan awal siswa dengan bertanya. Adanya model sebagai alat bantu penyampaian materi. Dilanjutkan dengan proses inkuiri melalui kegiatan diskusi antara siswa dengan guru, maupun sesama siswa. Hasil dari proses ini dipresentasikan melalui diskusi kelas dan diakhiri dengan refleksi berdasarkan pembelajaran yang telah dilakukan.

\section{Kelebihan dan Kekurangan Pendekatan Kontekstual}

Kelebihan dan kelemahan selalu terdapat dalam setiap model, strategi, atau metode pembelajaran. Namun, kelebihan dan kelemahan tersebut hendaknya menjadi referensi untuk penekanan-penekanan terhadap hal yang positif dan meminimalisir kelemahan-kelemahannya dalam pelaksanaan pembelajaran. Menurut Sanjaya (2006: 111) kelebihan pendekatan kontekstual adalah sebagai berikut: a. Menempatkan siswa sebagai subjek belajar, artinya siswa berperan aktif dalam proses pembelajaran. b. Dalam pembelajaran kontekstual siswa belajar dalam kelompok, kerjasama, diskusi, saling menerima dan memberi. c. Berkaitan secara riil dengan dunia nyata. d. Kemampuan berdasarkan pengalaman. e. Dalam pembelajaran kontekstual perilaku dibangun atas kesadaran sendiri. f. Pengetahuan siswa selalu berkembang sesuai dengan pengalaman yang dialaminya. g. Pembelajaran dapat dilakukan dimana saja sesuai dengan kebutuhan. $h$.
Pembelajaran kontekstual dapat diukur melalui beberapa cara, misalnya evaluasi proses, hasil karya siswa, penampilan, observasi, rekaman, wawancara, dll. Selanjutnya, Priansa (2015:238) menjelaskan juga mengenai kelebihan pendekatan pembelajaran kontekstual yakni pembelajaran lebih bermakna dan riil, artinya materi yang dipelajari akan tertanam erat dalam memori peserta didik dan tidak mudah terlupakan sehingga materi tersebut berfungsi secara fungsional. Pembelajaran lebih produktif dan mampu menumbuhkan penguatan konsep pada peserta didik yang menggunakan konsep konstruktivisme.

Kelemahan pendekatan kontekstual menurut Komalasari (2010: 15), yaitu (a) jika guru tidak pandai mengaitkan materi pembelajaran dengan kehidupan nyata siswa, maka pembelajaran akan menjadi monoton, (b) jika guru tidak membimbing dan memberikan perhatian yang ekstra, siswa sulit untuk melakukan kegiatan inkuiri, dan membangun pengetahuannya sendiri. Sementara itu Priansa (2015:239) menjelaskan kelemahan dari pendekatan pembelajaran kontekstula tersebut adalah guru lebih intensif membimbing dan guru mendorong ide dan mengembangkan strategi untuk belajar. Berdasarkan kajian yang telah dipaparkan tersebut, peneliti menyimpulkan bahwa pendekatan kontekstual merupakan pendekatan dengan konsep belajar mengajar yang mengaitkan antara materi yang diajarkan oleh guru dengan situasi dunia nyata siswa, dan mendorong siswa untuk membuat hubungan antara 
pengetahuan yang dimilikinya dengan penerapannya dalam kehidupan nyata.

Komponen dalam kontekstual meliputi proses konstruktivis, melakukan proses berpikir secara sistematis melalui inkuiri, kegiatan bertanya antara siswa dengan guru maupun sesama siswa, membentuk kerjasama antarsiswa melalui diskusi, adanya peran model untuk membantu proses pembelajaran, melibatkan siswa dalam melakukan refleksi pembelajaran, serta penilaian sebenarnya yang dilakukan selama proses pembelajaran berlangsung sampai diperoleh hasil belajar. Adapun langkah-langkah dalam penerapan pendekatan kontekstual, diawali dengan pengonstruksian pengetahuan yang dimiliki siswa dengan materi yang akan dipelajari, dan dikaitkan dengan konteks dunia nyata. Mengembangkan pengetahuan awal siswa dengan bertanya. Adanya model sebagai alat bantu penyampaian materi. Dilanjutkan dengan proses inkuiri melalui kegiatan diskusi antara siswa dengan guru, maupun sesama siswa. Hasil dari proses ini dipresentasikan melalui diskusi kelas dan diakhiri dengan refleksi berdasarkan pembelajaran yang telah dilakukan. Penilaian keseluruhan kegiatan pembelajaran dilakukan menggunakan penilaian autentik.

\section{SIMPULAN}

Melalui pembelajaran sejarah guru dapat mengembangkan pemahaman siswa tentang masa lalu dengan melakukan pembelajaran yang dapat menghubungkan antara materi sejarah dengan situasi nyata di sekitar siswa, sehingga siswa dapat menggambarkan peristiwa masa lalu tesebut seperti yang ada dalam pelajaran sejarah. Adapun inovasi tersebut dikenal dengan istilah pembelajaran kontekstual yang memiliki prinsip-prinsip, asas-asas dalam penerapannya dengan mengaitkan antara materi yang dipelajari dengan kehidupan nyata siswa sehari-hari, baik dalam lingkungan keluarga, sekolah, masyarakat maupun warga negara, dengan tujuan untuk menemukan makna materi tersebut bagi kehidupannya.

\section{DAFTAR PUSTAKA}

Abdullah, T. (1996). Sejarah Lokal di Indonesia. Yogyakarta: Gajah Mada University Press.

Alfian, M. (2011). Pendidikan Sejarah dan Permasalahan Yang Dihadapi. Jurnal Ilmiah Kependidikan Khazanah Pendidikan. 3(2)

Depdiknas. (2003). Pendekatan Kontekstual (Contextual Teaching and Learning (CTL). Jakarta. Ditjen Dikdasmen.

Hasan, S., H. (2003). Kurikulum Sejarah dan Pendidikan Sejarah Lokal. Makalah pada Seminar Nasional Kurikulum Berbasis Kompetensi. Bandung: UPI.

Isjoni. (2007). Pembelajaran Sejarah pada Satuan Pendidikan. Bandung: Alfabeta.

Johnson E., B. (2007). Contextual Teaching \& Learning Menjadikan Kegiatan BelajarMengajar Mengasyikkan dan Bermakna. Bandung: Mizan Learning Center (MLC). 
Komalasari, K. (2010). Pembelajaran Kontekstual, Konsep dan Aplikasi. Bandung: Refika Aditama.

Muchith, S. (2008). Pembelajaran Kontekstual. Semarang: $\mathrm{Ra}$ SAILL Media Grup.

Priansa, J., D. (2015). Manajemen Peserta Didik dan Model Pembelajaran. Bandung: Alfabeta.

Sanjaya, W. (2006). Strategi Pembelajaran Berorientasi Standar Proses Pendidikan. Jakarta. Kencana Prenada Media Grup.

Sugiyono. (2012). Metode Penelitian. Bandung : Gramedia.

Suprijono, A. (2010). Model Pembelajaran.Bandung:

PT.Remaja Rosdakarya.

Trianto. (2014). Model Pembelajaran Terpadu Konsep Strategi dan Implementasinya dalam Kurikulum Tingkat Satuan Pendidikan (KTSP). Jakarta. PT Bumi Aksara 